\title{
Occurrence of Agriotes wireworms in Austrian agricultural land
}

\author{
Karin Staudacher • Nikolaus Schallhart • Peter Pitterl • \\ Corinna Wallinger · Nina Brunner • Marion Landl • \\ Bernhard Kromp $\cdot$ Johann Glauninger $\cdot$ Michael Traugott
}

Received: 19 April 2011/Accepted: 26 September 2011/Published online: 13 October 2011

(C) The Author(s) 2011. This article is published with open access at Springerlink.com

\begin{abstract}
Agriotes wireworms (Coleoptera: Elateridae) are abundant soil-dwelling herbivores which can inflict considerable damage to field crops. In Europe up to 40 species occur, differing in their ecology and pest status. Their distribution in the larval stage, however, has rarely been assessed because of the considerable effort in collecting wireworms and the difficulties in identifying them to species-level. Here, we examined the occurrence of Agriotes wireworms in Austrian agricultural land with regard to their association with climatic and soil parameters. Using a molecular identification system, 1348 field-collected larvae from 85 sites were identified to species-level. Three species, Agriotes obscurus, Agriotes brevis, Agriotes ustulatus, and
\end{abstract}

Communicated by Dr. Donld C. Weber

Electronic supplementary material The online version of this article (doi:10.1007/s10340-011-0393-y) contains supplementary material, which is available to authorized users.

A contribution to the Special Issue on Ecology and Control of Wireworms

K. Staudacher $(\bowtie) \cdot$ N. Schallhart · P. Pitterl · C. Wallinger · M. Traugott

Mountain Agriculture Research Unit, Institute of Ecology, University of Innsbruck, Technikerstraße 25,

6020 Innsbruck, Austria

e-mail: karin.staudacher@uibk.ac.at

N. Brunner · B. Kromp

Bio Forschung Austria, Esslinger Hauptstraße 132-134,

1220 Vienna, Austria

M. Landl · J. Glauninger

Department of Applied Plant Sciences and Plant Biotechnology, Institute of Plant Protection, University of Natural Resources and Applied Life Sciences, Peter Jordan Straße 82, 1190 Vienna, Austria two that could not be discerned molecularly (Agriotes lineatus and Agriotes proximus), were assigned to two ecological groups: (i) A. brevis/A. ustulatus, found in areas with a warmer, drier climate and alkaline soils, and (ii) A. obscurus/ A. lineatus/proximus which occur mainly at higher altitude characterised by lower temperatures, higher precipitation and acidic, humus-rich soils. Agriotes sputator was abundant throughout Austria, confirming its euryoecious nature. Only one larva of Agriotes litigiosus was found, prohibiting further analysis. These data contribute to a characterisation of species-specific traits in Agriotes larvae in agricultural land, an important prerequisite to develop efficient control strategies for these wireworms.

Keywords Elateridae $\cdot$ Pest control $\cdot$ Molecular identification - Adrastus spp. · Climatic factors $\cdot \mathrm{pH}$

\section{Introduction}

The larvae of Agriotes click beetles (Coleoptera: Elateridae), also referred to as wireworms, are abundant soildwelling insects representing the long-lived stage (i.e. 3-5 years, Dobrovolsky 1970). They are predominantly herbivorous (Traugott et al. 2008) and serious agricultural pests, attacking field crops such as potatoes and maize (Hill 1987; Parker and Howard 2001). Throughout Europe up to 40 Agriotes species occur (Cate 2007); some of them have been studied in detail (e.g. Furlan 1998, 2004; Kabanov 1975; Langenbuch 1932; Traugott et al. 2008), revealing differences in species-specific traits such as phenology, feeding behaviour and preferred environmental conditions. Still, for most Agriotes species, no precise data of their pest status and actual distribution in agricultural land are available which hampers the development of efficient pest 
control strategies (Parker and Howard 2001). In terms of their control, trap cropping offers a great potential (Vernon et al. 2000, 2005), yet it remains unknown whether species-specific dietary choices might influence the attraction of intercropped plant species. Similarly, the efficacy of entomopathogenic fungi and nematodes can vary amongst different Agriotes species (Jossi et al. 2008). The success of biofumigation also depends on species-specific traits (Furlan et al. 2010). In addition, behavioural as well as physiological differences between species are likely to affect the impact of soil-applied insecticides (Vernon et al. 2008).

Historically, few studies have focussed on Agriotes wireworm occurrence and species composition in agricultural land (Alekhin 1973; Jossi and Bigler 1997; Landl et al. 2010). Most studies have targeted adult male beetles as these can be easily collected in pheromone traps (e.g. Furlan and Tóth 2007; Subchev et al. 2005; Vernon and Tóth 2007). Although monitoring via pheromone trapping provides an effective means to collect adult male beetles (Tóth et al. 2003), there are constraints to this approach: for example, the long-lived larval population in the soil is not necessarily reflected by adult catches (Hicks and Blackshaw 2008; Landl et al. 2010). Moreover, pheromones are not available for all Agriotes species, rendering the adult species spectrum incomplete. Extensive field surveys of wireworms, on the other hand, entail time-consuming and laborious soil sampling and it is difficult to morphologically identify Agriotes wireworms to species-level. The latter can be resolved by applying a recently developed molecular identification system (Staudacher et al. 2011), which offers a reliable tool for identifying and monitoring Agriotes larvae typically found in Central Europe.

In Austria 14 Agriotes species have been identified (Cate 2007), yet it is unknown which species are most widespread and harmful in agricultural land and how the occurrence of these species is characterised by environmental factors. The present study had two aims: (i) to examine the species-specific occurrence of Agriotes wireworms in Austrian agricultural land and (ii) to analyse how the species requirements differ with regard to climatic and soil parameters.

\section{Materials and methods}

\section{Collection of wireworms}

Between 2007 and 2009, Agriotes larvae were collected in the course of numerous local studies at 85 agricultural sites throughout Austria (ESM 1). Several regions were chosen to cover the broad spectrum of environmental parameters present in Austria: the eastern foothills of the Alps and the periphery of the Pannonian Plain, the Austrian granite plateau located in the north (Bohemian Mass) and the alpine area in the western part of the country. Within regions the selection of the agricultural sites relied on monitored information about wireworm-induced damage. The sites included organic and conventional fields, planted with different crops (e.g. potato, maize) and grasslands (Table 1, ESM 2). The latter were investigated, as wireworms are typically linked to grassland in a rotation, where they can establish damaging populations, being present when a crop is sown (Blackshaw and Kerry 2008; Parker and Howard 2001). The wireworm sampling differed in mode and/or frequency based on the varying foci of the local studies. All wireworms were manually collected from a minimum of six soil samples or cereal baited traps per site and individually stored, either in $70-90 \%$ ethanol or frozen at $-28^{\circ} \mathrm{C}$.

\section{Wireworm species identification}

Aside from some Agriotes ustulatus larvae $(n=54$, Table 1), which could be identified based on their distinct morphological characters (Klausnitzer 1994), all larvae investigated here were identified by molecular means as described in Staudacher et al. (2011). The remains of these larvae were stored in our laboratory at Innsbruck University and are available for further examination. The two species Agriotes lineatus and Agriotes proximus remained molecularly indistinguishable because of the low interspecific sequence divergence as reported earlier (Staudacher et al. 2011). DNA extracts which did not amplify in the diagnostic multiplex PCRs were sequenced to barcode these specimens.

The DNA barcoding revealed that several specimens which were assigned to the genus Agriotes during field sampling had a perfect match with sequences of Adrastus spp., an elaterid genus which is morphologically very similar to Agriotes spp. in the larval stage (Klausnitzer 1994). Hence, specific primers targeting Adrastus spp. were designed to reduce the number of specimens which needed to be sequenced. The newly developed primers Adr-spp-S540 (5'-AACTGACTTGTTCCTCTAATACTG-3' ${ }^{\prime}$ and Adr-spp-A549 (5'-CGATCAAATGAA ATTCCAAC- $3^{\prime}$ ) amplify a $302 \mathrm{bp}$ fragment of the mitochondrial cytochrome $c$ oxidase subunit I gene. The specificity of this primer pair was tested against all Central European Agriotes species as well as against other elaterid species [e.g. Agrypnus murinus (L.), Hemicrepidius niger (L.)] and nonelaterid soil invertebrates (see list of non-target species in Staudacher et al. 2011). Each $10 \mu \mathrm{l} \mathrm{PCR} \mathrm{contained} 1.5 \mu \mathrm{l}$ of DNA extract, $0.375 \mathrm{U}^{\text {BioTherm }}{ }^{\mathrm{TM}}$ Taq DNA Polymerase (Ares Bioscience, Köln, Germany), $1 \mu \mathrm{l} 10 \times$ Reaction Buffer, $3 \mathrm{mM} \mathrm{MgCl}_{2}, 0.2 \mathrm{mM}$ dNTPs (Ares Bioscience), $1 \mu \mathrm{M}$ of each primer, $5 \mu \mathrm{g}$ bovine serum albumin (BSA) and $3.325 \mu \mathrm{l}$ PCR-grade RNase-free water (Qiagen, Hilden, Germany). The thermocycling program (executed on a Mastercycler Gradient, Eppendorf, Hamburg, Germany) consisted 
Table 1 Agriotes larvae collected in Austrian agricultural land (' $E$ ', ' $N$ ' and ' $W$ ' indicate eastern, northern, and western [i.e. alpine] part, of the country) and identified by molecular means as described in

\begin{tabular}{|c|c|c|c|c|c|c|c|c|}
\hline Region & $\begin{array}{l}\text { No. of } \\
\text { sites }\end{array}$ & $\sum_{\text {larvae }}$ Agriotes & $\begin{array}{l}\text { Agriotes } \\
\text { obscurus } \\
\text { (L.) }\end{array}$ & $\begin{array}{l}\text { Agriotes } \\
\text { sputator (L.) }\end{array}$ & $\begin{array}{l}\text { Agriotes } \\
\text { brevis } \\
\text { Candèze }\end{array}$ & $\begin{array}{l}\text { Agriotes } \\
\text { ustulatus } \\
\text { (Schaller) }\end{array}$ & $\begin{array}{l}\text { A. lineatus (L.)/ } \\
\text { A. proximus } \\
\text { Schwarz }\end{array}$ & $\begin{array}{l}\text { Agriotes } \\
\text { litigiosus } \\
\text { (Rossi) }\end{array}$ \\
\hline Pannonian Plain (E) & 5 & 54 & & 3 & 35 & $16(14)$ & & \\
\hline Marchfeld (E) & 9 & 150 & 1 & 5 & 131 & $13(1)$ & & \\
\hline Wein-/Mostviertel (E-N) & 27 & 203 & 37 & 60 & 51 & $55(39)$ & & \\
\hline Wald-/Mühlviertel (N) & 14 & 126 & 34 & 78 & 11 & & 3 & \\
\hline Inn-/Hausruckviertel (N) & 9 & 93 & 52 & 22 & 11 & 2 & 5 & 1 \\
\hline Tyrol (W, Alps) & 21 & 616 & 465 & 151 & & & & \\
\hline$\Sigma$ & 85 & 1242 & 589 & 319 & 239 & $86(54)$ & 8 & 1 \\
\hline
\end{tabular}

Staudacher et al. (2011) (numbers in parenthesis represent morphologically identified Agriotes ustulatus larvae) of an initial activation step of $2 \mathrm{~min}$ at $94^{\circ} \mathrm{C}$, followed by 35 cycles of $20 \mathrm{~s}$ at $94^{\circ} \mathrm{C}, 30 \mathrm{~s}$ at $50^{\circ} \mathrm{C}, 45 \mathrm{~s}$ at $72^{\circ} \mathrm{C}$ and a $2 \mathrm{~min}$ final extension at $72^{\circ} \mathrm{C}$. PCR products were electrophoresed on $1.5 \%$ agarose gels stained with GelRed ${ }^{\mathrm{TM}}$ (Biotium, Hayward, USA) and visualized under UV light.

Environmental factors and statistical analyses

The distribution of Agriotes species within the Austrian sampling sites was displayed on maps created in $\mathrm{ESRI}^{\circledR}$ ArcGIS 9.3 (ESRI, Redlands, USA). Geographic (ESRI Data \& Maps 2006, Media Kit) and climatic parameters (WorldClim, Hijmans et al. 2005) were obtained from freely accessible data layers. Presence/absence data of the different species and not their abundances were used for statistical analyses as the sampling was done in a qualitative manner. One-way ANOVAs were used to evaluate environmental factors, i.e. altitude, annual mean temperature and annual precipitation, for significant differences between the sites. All sampling sites located up to $8.2 \mathrm{~km}$ distance between each other were pooled, as they share similar climatic conditions, reducing the 85 sites to 25 areas. These analyses were conducted in PASW Statistics 18 (SPSS Inc., Chicago, USA).

Multivariate analyses were performed with CANOCO for Windows 4.5 (ter Braak and Šmilauer 2002) considering every single site. Canonical correspondence analysis (CCA) was used to examine how species distribution was related to climatic parameters (i.e. altitude, annual mean temperature, annual precipitation, temperature/precipitation seasonality, winter/summer temperature extremes, winter/summer precipitation and isothermality). Likewise, site-specific soil parameters ( $\mathrm{pH}$, lime concentration, water-holding capacity and water permeability, humus content, agricultural suitability and land value) obtained from soil maps from the eBOD database ('Digitale Bodenkarte von Österreich, BFW') were correlated with the occurrence of Agriotes species. Statistical significance of axes was tested using Monte Carlo permutation tests (999 permutations under the reduced model). Because the sampling design was not laid out for a comparison between organic and conventional sites or between different crops, these variables were not contrasted in our analysis.

\section{Results}

Agriotes larvae from Austrian agricultural land

Within the 85 sampling sites, six Agriotes species comprising 1,242 individuals were identified: A. obscurus, A. sputator, A. brevis, A. ustulatus, A. litigiosus and the two indistinguishable species $A$. lineatus and $A$. proximus (Table 1, ESM 1). Within $50 \%$ of the investigated sites, more than one Agriotes species was recorded; at three sites a maximum of four species co-occurred. In addition, 92 larvae of Adrastus spp. were identified via the Adrastusspecific PCR and DNA barcoding. Only 14 specimens of the field-collected wireworms did not provide amplifiable DNA.

Agriotes obscurus was most frequently found ( $n=589)$, especially in the alpine area (Tyrol), followed by $A$. sputator $(n=319)$. Agriotes brevis $(n=239)$ and A. ustulatus ( $n=86$ ), however, were only found in the northern and eastern parts of the country. Agriotes lineatus/proximus was occasionally found in lower numbers and A. litigiosus was represented by a single larva collected in the Hausruckviertel (Fig. 1; Table 1).

Climatic parameters and the occurrence of Agriotes larvae

Significant differences in the altitudinal occurrence of the Agriotes wireworms were found for five species ( $F$-ratio 
Fig. 1 Agricultural sites in Austria where different Agriotes wireworms were found
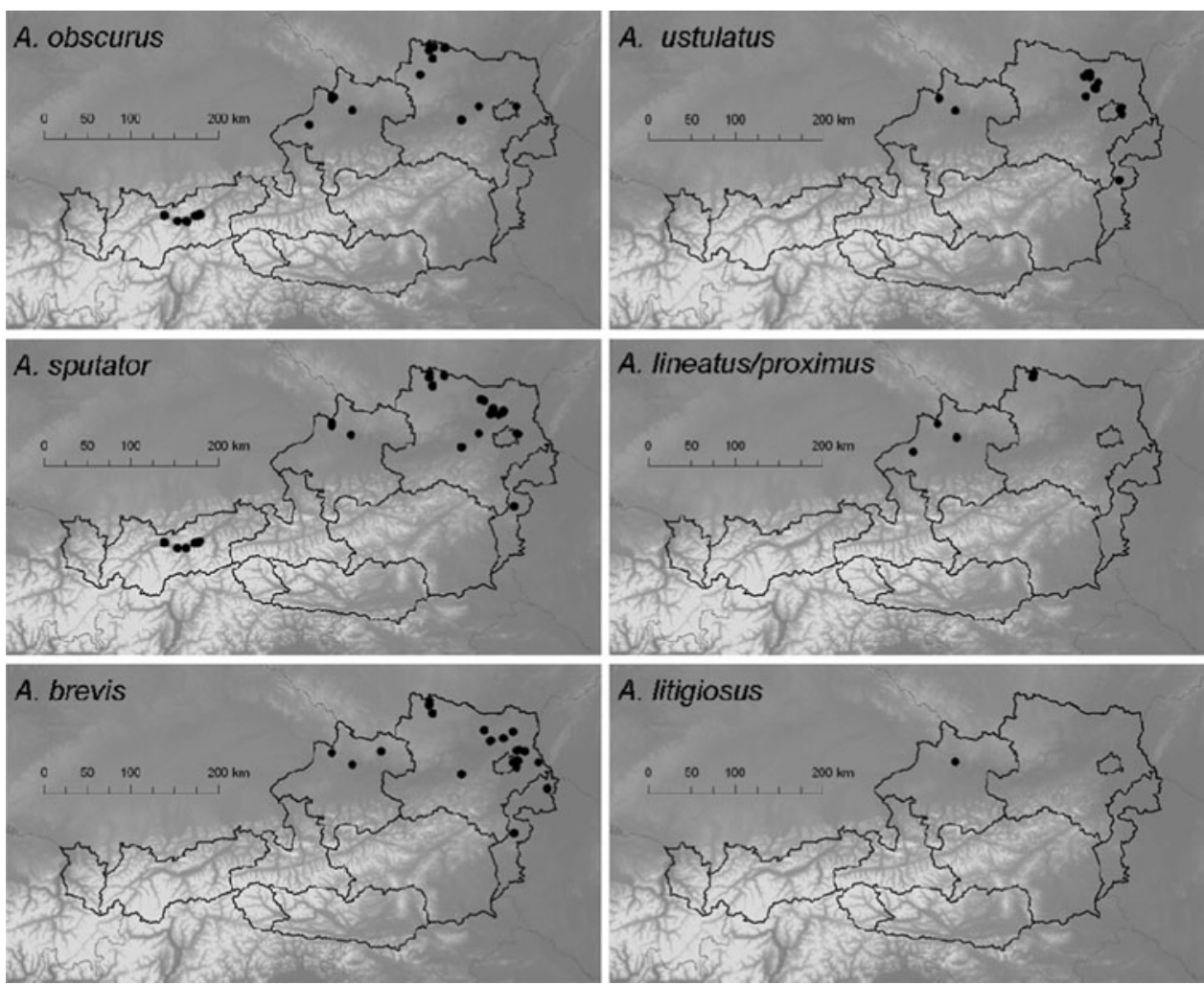

$=2.924, P=0.03$; single count for $A$. litigiosus not considered): A. obscurus larvae were collected on sites with a mean altitude of $481.8 \mathrm{~m}$ a.s.1., which was higher compared to the mean altitude where wireworms of $A$. brevis and A. ustulatus were found (304.7 and $279 \mathrm{~m}$, respectively). The distributional centre of A. lineatus/proximus and A. sputator larvae was around $430 \mathrm{~m}$ a.s.1. (Fig. 2a). In terms of climaterelated species occurrence, only annual precipitation values were found to be significantly different between species $(F$ ratio $=2.593, P=0.047)$. Annual precipitation at the preferred sites of A. lineatus/proximus and A. obscurus larvae averaged 953.8 and $833.5 \mathrm{~mm}$, respectively. The larvae of $A$. brevis, A. ustulatus and A. sputator occurred in regions with lower annual precipitation, averaging between 715.1, 731.4 and $765.3 \mathrm{~mm}$, respectively (Fig. 2b). The preferred sites of A. lineatus/proximus and A. obscurus were also characterised by lower annual mean temperatures (averaged 8.15 and $8.36^{\circ} \mathrm{C}$, respectively), whereas larvae of A. brevis, A. ustulatus and $A$. sputator preferred sites with higher annual mean temperatures (averaged $8.94,9.13$ and $8.7^{\circ} \mathrm{C}$, respectively) (Fig. 2c).

Similar relationships were found when performing a CCA (Fig. 3): the arrangement of the five Agriotes species along the first axis (eigenvalue $=0.408, F$-ratio $=18.733$, $P=0.001$ ) clearly corresponds to the altitudinal gradient. The occurrence of $A$. obscurus and A. lineatus/proximus correlates positively with rising altitude, accompanied by increasing annual precipitation (mean, summer and winter values, respectively). In contrast, $A$. brevis and $A$. ustulatus tend to be more frequent with increasing annual mean temperature and temperature seasonality as well as maximum temperature in the warmest month and minimum temperature in the coldest month (extremes). The second axis (eigenvalue $=0.194$ ) separates A. lineatus/proximus from all the other species because of its occurrence on sites characterised by high precipitation during the winter months.

Soil parameters and the occurrence of Agriotes larvae

The CCA of the Agriotes species distribution and different soil parameters (Fig. 4) resulted in a separation along the first axis (eigenvalue $=0.190, F$-ratio $=7.972$, $P=0.003$ ) according to soil $\mathrm{pH}$. This gradient corresponds to a separation of $A$. ustulatus (sites with higher $\mathrm{pH}$ values/ lime concentrations) from $A$. brevis/A. sputator and $A$. obscurus/A. lineatus/proximus (sites with lower $\mathrm{pH}$ ). The second axis (eigenvalue $=0.090$ ) roughly separates the agricultural sites according to water balance-related parameters. Here, the occurrence of A. brevis larvae correlates with increased water permeability of the soil compared to the other species. Agriotes obscurus and A. lineatus/ proximus wireworms were found more frequently in humusrich soils, the latter correlating positively with higher waterholding capacity. 

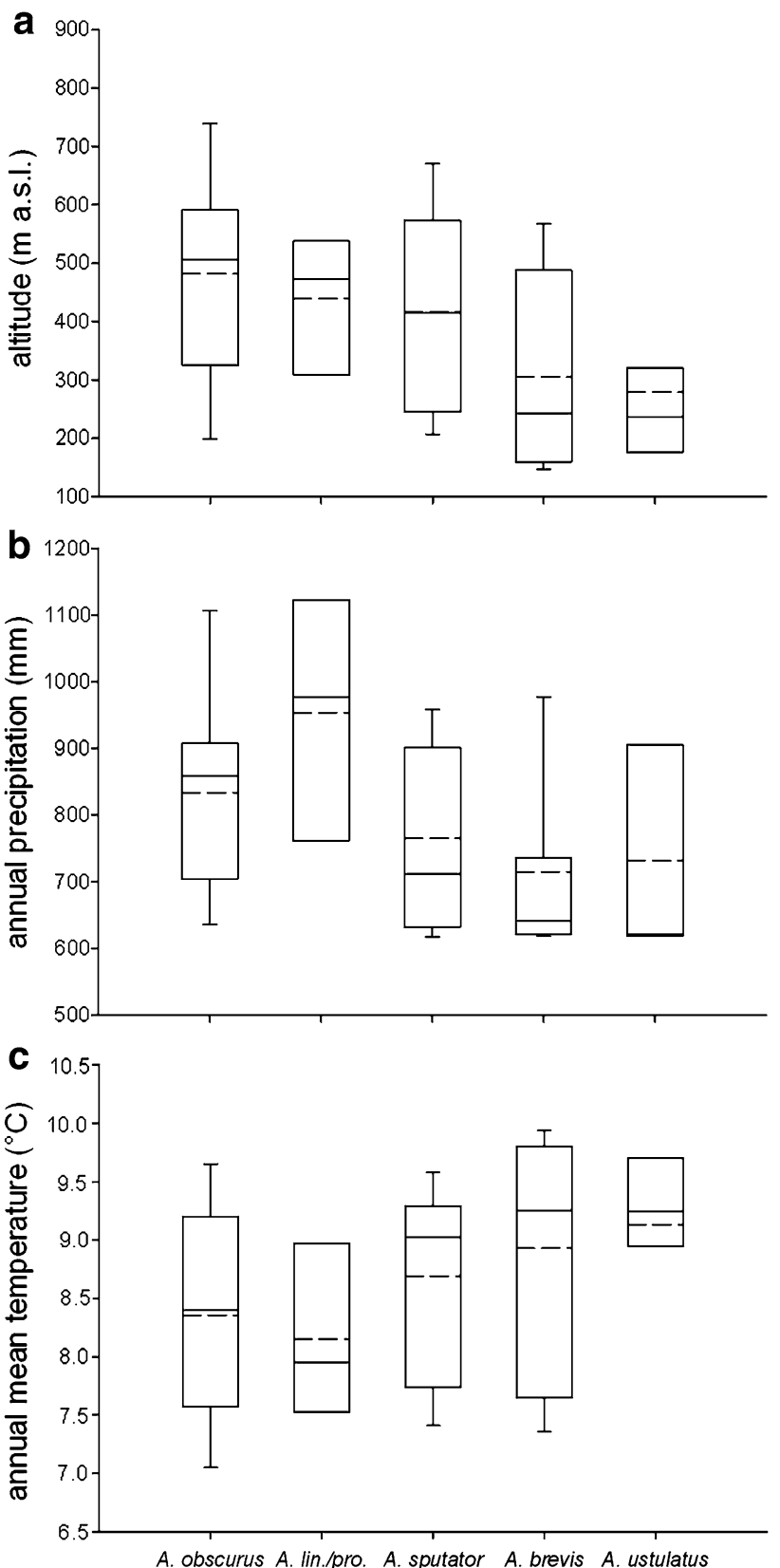

Fig. 2 Occurrence of five Agriotes species (Agriotes lineatus/proximus abbreviated as A. lin./pro.) in Austrian agricultural land with regard to $\mathbf{a}$ altitude, $\mathbf{b}$ annual precipitation and $\mathbf{c}$ annual mean temperature. Box-plots display the median, 25 and 75th percentiles (line, box), arithmetic mean (dashed line) and the 10 and 90th percentiles (whiskers). Number of areas where species occur are: 14 (A. obscurus), 4 (A. lin./pro.), 16 (A. sputator), 15 (A. brevis) and 7 (A. sputator)

\section{Discussion}

This study represents the first extensive field survey of Agriotes wireworms in Austrian agricultural land. We detected six out of 14 Agriotes species known to occur in Austria. Agriotes obscurus, A. sputator, A. brevis and A. ustulatus were found to be the most abundant species,

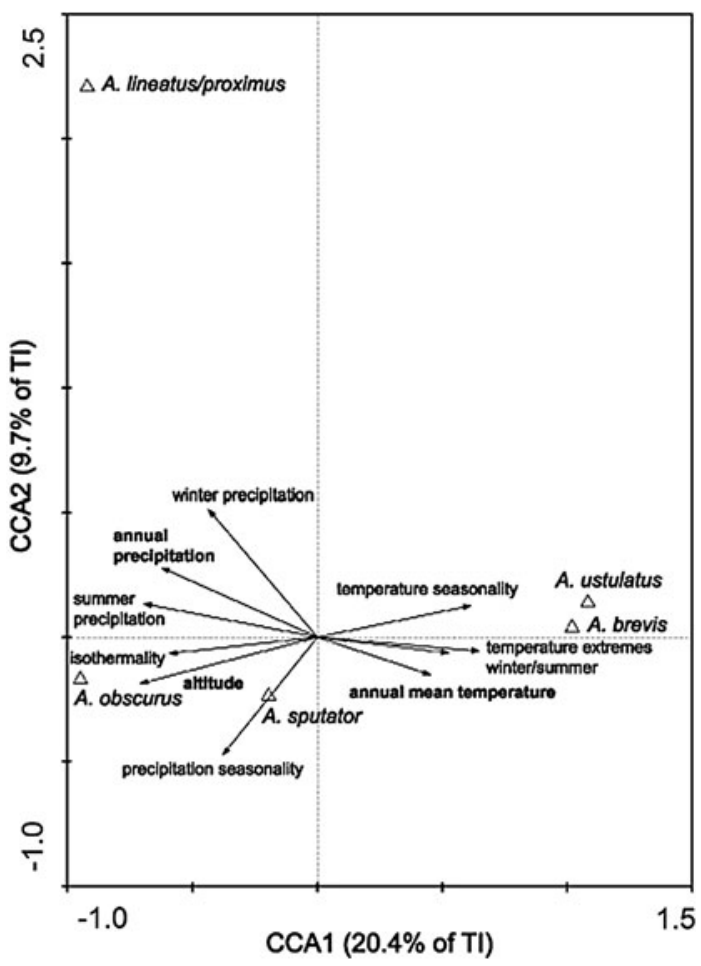

Fig. 3 Canonical correspondence analysis of climatic parameters (vectors) and five Agriotes species (indicated by triangles) based on their occurrence in agricultural land in Austria $(n=85)$. Ordination biplot for 1st (CCA1) and 2nd axis (CCA2); variation explained by axes is given as a percentage of total variation (total inertia, TI)

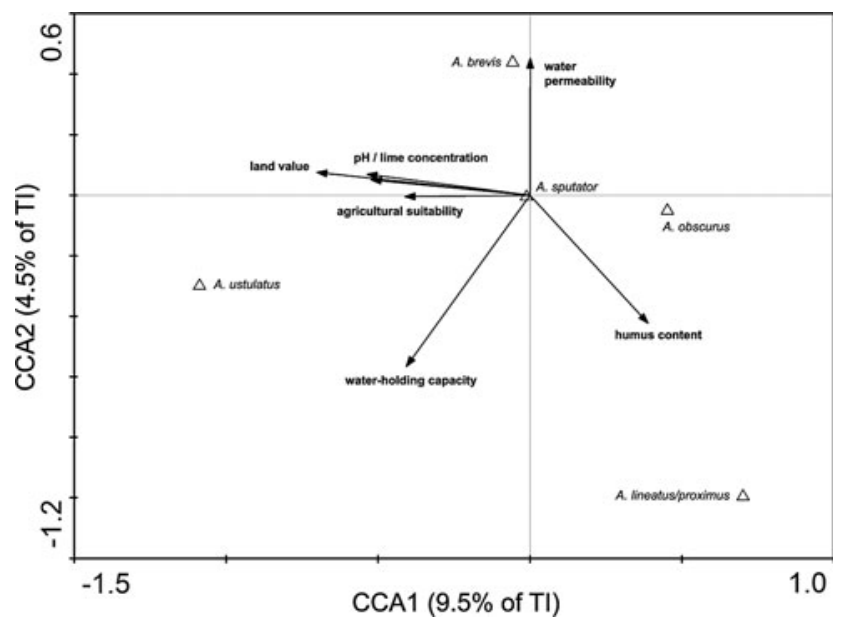

Fig. 4 Canonical correspondence analysis of soil parameters (vectors) and five Agriotes species (indicated by triangles) based on their occurrence in agricultural land in Austria $(n=85)$. Ordination biplot for 1st (CCA1) and 2nd axis (CCA2); variation explained by axes is given as a percentage of total variation (TI)

confirming their importance in arable land and corroborating observations from other parts of Europe (e.g. Furlan and Tóth 2007; Jossi and Bigler 1997; Tóth 1984). The 
remaining species absent in this study are either rare or do not occur in arable fields and exposed grasslands.

By collecting a large number of wireworms throughout the country we were able to assign four Agriotes species (A. lineatus/A. proximus as a group) to two ecological groups, each showing a preference for distinct environmental conditions. One group (A. brevis and A. ustulatus) dominated in areas with a warmer and drier climate than the other group (A. lineatus/proximus and A. obscurus) which occurred mainly at higher altitudes, characterised by lower temperatures and higher precipitation. Aside from these species, A. sputator larvae were found to be widespread, confirming the species' euryoecious nature (Franz 1974; Wörndle 1950). Likewise, Alekhin (1973) showed that $A$. sputator occurs in six different climatic regions in Russia, ranging from the forest-steppe zone to the Volga delta. The single count for A. litigiosus prohibited any further analysis in the present study.

The majority of the sites where larvae of A. obscurus occurred were located in the western, alpine region (Tyrol) and higher reaches of Upper and Lower Austria. This fits the previously described distribution of this species (adult beetles) in the northern parts of Austria and higher altitudes (Franz 1974; Jossi and Bigler 1997; Wörndle 1950), also indicating that this species generally favours lower temperatures. Previous studies showed that A. obscurus was, apart from grasslands, very abundant in maize/potato fields in Tyrol (Schallhart et al. 2009; Traugott et al. 2008). Langenbuch (1932) showed that late instar A. obscurus wireworms can survive several hours at $-14^{\circ} \mathrm{C}$ and are frost resistant over several weeks. Literature data indicate that the preferred environmental conditions of A. lineatus are comparable to A. obscurus (Kabanov 1975; Langenbuch 1932; Schimmel 1989; Tóth 1984). Indeed, in the present study, larvae of A. lineatus/proximus were found only in northern Austria (Waldviertel-Innviertel), characterised by high mean annual precipitation (see also Landl et al. 2010). Agriotes lineatus is known to be hydrophilic and especially moisture-resistant (Langenbuch 1932), and according to Kabanov (1975) these wireworms are able to survive flooding over several days. The current data indicate that A. lineatus/proximus and A. obscurus larvae have similar preferences regarding the examined soil parameters, i.e. soil acidity and humus-richness.

Larvae of A. brevis and A. ustulatus were mostly restricted to the eastern parts of Austria, ranging from Upper Austria (Waldviertel-Weinviertel) to the periphery of the Pannonian plain. This result confirms the preference of A. ustulatus for warmer and drier climates described earlier (Furlan 1998). Previous investigations showed that this species mainly occurs in Southern/Central-Eastern Europe (Furlan and Tóth 2007; Franz 1974; Schimmel 1989; Wörndle 1950). Rusek (1972) and Franz (1974) suggested that A. brevis also favours higher mean annual temperatures and less precipitation. In the present study, this species was found more frequently in sandy, humuspoor soils.

So far, only a few investigations on Agriotes wireworm occurrence have been conducted in Austria (Brunner et al. 2005; Landl et al. 2010) which depended on laborious and uncertain morphological larval identification. The present study demonstrates the applicability of the molecular identification protocol for large scale surveys: $92 \%$ of all collected wireworms were directly identified via multiplex PCRs, which proved to be highly suitable to cover the key Agriotes species present in agricultural land in Central Europe. Furthermore, we provide new Adrastus spp. primers, allowing the differentiation of these wireworms (e.g. Adrastus montanus (Scopoli)) from the very similar looking Agriotes larvae. The new primers will be useful for studies dealing with other wireworm genera where identification to species level was not yet possible (Benefer et al. 2010; Parker and Seeney 1997; Samson and Calder 2003).

\section{Conclusion}

The present data provide both new insights into the occurrence of Agriotes larvae in Austria and a better characterisation of species-specific traits, i.e. information on environmental factors which drive the distribution of Agriotes larvae in agricultural land. As behavioural and phenological differences between species affect the efficacy of control strategies such as trap cropping or the use of entomopathogens and insecticides, these data will be helpful to develop species-specific control strategies.

Acknowledgements This research was supported by the 'BundBundesländerkooperations (BBK)' project 1448 'New approaches to regulate wireworms, with a special emphasis on organic farming' and the project 'Exploitation of plant diversity by below-ground herbivores' funded by the Austrian Science Fund (FWF): P20377-B17. We would like to thank Anita Juen, Julia Seeber, Daniela Sint and Lorna Raso for valuable discussion and Donald C. Weber and two anonymous reviewers for commenting on the manuscript.

Open Access This article is distributed under the terms of the Creative Commons Attribution Noncommercial License which permits any noncommercial use, distribution, and reproduction in any medium, provided the original author(s) and source are credited.

\section{References}

Alekhin VA (1973) The species composition of wireworms (Coleoptera, Elateridae) in beet plantings in the southeast of the Europeas part of the USSR. Entomol Rev 52:342-346 
Benefer C, Andrew P, Blackshaw R, Ellis J, Knight M (2010) The spatial distribution of phytophagous insect larvae in grassland soils. Appl Soil Ecol 45:269-274

Blackshaw R, Kerry B (2008) Root herbivory in agricultural ecosystems. In: Johnson SN, Murray PJ (eds) Root feeders: an ecosystem perspective. CAB International, Wallingford, pp 35-53

Brunner N, Kromp B, Meindl P, Pázmándi C, Traugott M (2005) Evaluation of different sampling techniques for wireworms (Coleoptera, Elateridae) in arable land. IOBC/wprs Bulletin 28:117-122

Cate PC (2007) Elateroidea (-Cebrioninae, Lissominae, Subprotelaterinae). In: Löbl I, Smetana A (eds) Catalogue of palaearctic coleoptera, vol 4. Apollo Books, Stenstrup, pp 94-209

Dobrovolsky BV (1970) Biological grounds for plant protection against wireworms in the USSR. Pedobiologia 10:26-44

Franz H (1974) Die Nord-Ost Alpen im Spiegel ihrer Landtierwelt. Eine Gebietsmonographie. Band IV Coleoptera, 2 Teil. Universitätsverlag Wagner, München

Furlan L (1998) The biology of Agriotes ustulatus Schäller (Col., Elateridae). II larval development, pupation, whole cycle description and practical implications. J Appl Entomol 122: $71-78$

Furlan L (2004) The biology of Agriotes sordidus Illiger (Col., Elateridae). J Appl Entomol 128:696-706

Furlan L, Tóth M (2007) Occurrence of click beetle pest spp. (Coleoptera, Elateridae) in Europe as detected by pheromone traps: survey results of 1998-2006. Integrated control of soil insect pests. IOBC/wprs Bulletin 30:19-25

Furlan L et al (2010) The efficacy of biofumigant meals and plants to control wireworm populations. Ind Crop Prod 31:245-254

Hicks H, Blackshaw R (2008) Differential responses of three Agriotes click beetle species to pheromone traps. Agric For Entomol 10:443-448

Hijmans RJ, Cameron SE, Parra JL, Jones PG, Jarvis A (2005) Very high resolution interpolated climate surfaces for global land areas. Int J Climatol 25:1965-1978

Hill DS (1987) Agricultural insect pests of temperate regions and their control. Cambridge University Press, Cambridge

Jossi W, Bigler F (1997) Auftreten und Schadenprognose von Drahtwürmern in Feldkulturen. Agrarforschung 4:157-160

Jossi W, Schweizer C, Keller S (2008) Schnellkäferarten und biologische Bekämpfung der Drahtwürmer. Agrarforschung 15:76-81

Kabanov VA (1975) Über Vorkommen und Entwicklung von Agriotes lineatus (Coleoptera, Elateridae) im europäischen Teil der UDSSR. Pedobiologia 15:98-105

Klausnitzer B (1994) Familie Elateridae. In: Klausnitzer B (ed) Die Larven der Käfer Mitteleuropas. Band 2, Myxophaga/Polyphaga, Teil 1. Gustav Fischer Verlag, Jena, pp 118-189

Landl M, Furlan L, Glauninger J (2010) Seasonal fluctuations in Agriotes spp. (Coleoptera: Elateridae) at two sites in Austria and the efficiency of bait trap designs for monitoring wireworm populations in the soil. J Plant Dis Prot 117:268-272

Langenbuch R (1932) Beiträge zur Kenntnis der Biologie von Agriotes lineatus L. und Agriotes obscurus L. Zeitschrift für angewandte Entomologie 19:278-300
Parker WE, Howard JJ (2001) The biology and management of wireworms (Agriotes spp.) on potato with particular reference to the U. K. Agric For Entomol 3:85-98

Parker WE, Seeney FE (1997) An investigation into the use of multiple site characteristics to predict the presence and infestation level of wireworms (Agriotes spp., Coleoptera: Elateridae) in individual grass fields. Ann Appl Biol 130:409-425

Rusek J (1972) Über Aktivität und Verteilung der Käfer von Agriotes brevis (Coleoptera, Elateridae) auf Äckern Süd-Mährens. Pedobiologia 12:149-155

Samson PR, Calder AA (2003) Wireworm (Coleoptera: Elateridae) identity, monitoring and damage in sugarcane. Aust $\mathrm{J}$ Entomol 42:298-303

Schallhart N, Wallinger C, Juen A, Traugott M (2009) Disperal abilities of adult click beetles in arable land revealed by analysis of carbon stable isotopes. Agric For Entomol 11:333-339

Schimmel R (1989) Monographie der rheinland-pfälzischen Schnellkäfer (Insecta: Coleoptera: Elateridae). Pollichia-Buch Nr. 16, Bad Dürkheim

Staudacher K, Pitterl P, Furlan L, Cate PC, Traugott M (2011) PCRbased species identification of Agriotes larvae. Bull Entomol Res 101:201-210

Subchev M, Toshova T, Furlan L, Tóth M (2005) Click beetles (Coleoptera, Elateridae) and their seasonal swarming as established by pheromone traps in different plant habitats in Bulgaria. Acta Zool Bulgarica 57:321-332

ter Braak CJF, Šmilauer P (2002) CANOCO reference manual and canodraw for windows user's guide: software for canonical community ordination (version 4.5). Microcomputer Power, Ithaca NY

Tóth Z (1984) Click beetles (Elateridae) in the soils of Central Europe-their distribution and description. Part I. (Gen.: Agriotes). Acta Phytopathol Acad Sci Hung 19:13-29

Tóth M et al (2003) Identification of pheromones and optimization of bait composition for click beetle pests (Coleoptera: Elateridae) in Central and Western Europe. Pest Manag Sci 59:417-425

Traugott M, Schallhart N, Kaufmann R, Juen A (2008) The feeding ecology of elaterid larvae in central European arable land: new perspectives based on naturally occurring stable isotopes. Soil Biol Biochem 40:342-349

Vernon RS (2005) Aggregation and mortality of Agriotes obscurus (Coleoptera: Elateridae) at insecticide-treated trap crops of wheat. J Econ Entomol 98:1999-2005

Vernon RS, Tóth M (2007) Evaluation of pheromones and a new trap for monitoring Agriotes lineatus and Agriotes obscurus in the Fraser valley of British Columbia. J Chem Ecol 33:345-351

Vernon RS, Kabaluk T, Behringer A (2000) Movement of Agriotes obscurus (Coleoptera: Elateridae) in strawberry (Rosaceae) plantings with wheat (Gramineae) as a trap crop. Can Entomol 132:231-241

Vernon RS et al (2008) Transitional sublethal and lethal effects of insecticides after dermal exposures to five economic species of wireworms (Coleoptera: Elateridae). J Econ Entomol 101: 365-374

Wörndle A (1950) Die Käfer von Nordtirol Faunistisches Verzeichnis der aus dem Gebiet bisher bekannt gewordenen Koleopteren. Universitätsverlag Wagner, Innsbruck, pp 215-222 